\title{
Inequality, Poor Governance and Legitimacy Deficits in the European Union
}

\author{
Michael Longo \\ Victoria University, Australia \\ George Messinis \\ Victoria University, Australia
}

\begin{abstract}
This article offers an interdisciplinary perspective on the drivers of political and economic crisis in the European Union. A growing body of literature highlights the detrimental effects of extractive institutions on opportunity, sustainable growth and social cohesion. The article therefore examines the link between income inequality, corruption and perceptions of illegitimacy in the European Union. It conjectures that poor institutional quality and governance are critical drivers of the European Union's legitimacy deficit. The article concludes that for the European regional project to advance there is a need for greater institutional convergence amongst member states and a renewed commitment to social cohesion.
\end{abstract}

Key Words

European Union, inequality, governance, legitimacy.

\section{Introduction}

From its inception the European Union (EU) has drawn generously, and gained inspiration, from the imperative of an ever-closer union. An epoch-making vocabulary emerged over half a century of development, which seemed to express the EU's objectives to improve the lives of all of its citizens. Words and sentiments such as 'solidarity', 'cohesion', and 'integration' itself, proved self-fulfilling as the EU marched towards peace and prosperity - the original twin imperatives of European integration (EI). However, the upheaval following the financial crisis of 2008 and the onset of systemic financialeconomic-political crises unprecedented in the post second world war period have challenged the tenets of EI while austerity has consigned debtor states to recession or low growth, accentuating social inequalities.

As the economic and social problems persist, the disintegration of the Eurozone still appears plausible. While the European Commission pleads for greater unity, its federative proposals are not enthusiastically received by many EU citizens who are increasingly disenchanted with globalisation and its European counterpart, Europeanisation. Populism is on the rise across Europe, and many citizens are now viewing the EU as the source of their problems (Longo and Murray 2011). More and more citizens in many member states have lost faith in the EU as a system, most now thinking that EI has weakened their country. ${ }^{1}$ The prescription of austerity is nourishing existing divergences in the economic and social condition of member states. While purporting to present a critical solution to

Copyright (C) 2016 Victoria. This document has been published as part of the Journal of Law and Governance in both online and print formats. Educational and non-profit institutions are granted a non-exclusive licence to utilise this document in whole or in part for personal or classroom use without fee, provided that correct attribution and citation are made and this copyright statement is reproduced. Any other usage is prohibited without the express permission of the publisher. sovereign indebtedness, austerity seems incapable of simultaneously resolving sovereign debt problems and stimulating sustainable growth. Furthermore, citizens are challenging the wisdom of austerity in the light of inequality, continuing governance failures and poor institutions ${ }^{2}$ that distort markets (i.e., barriers to entry, tax avoidance, corporate welfare, monopoly rights, policy capture or 
corruption) and lead to social exclusion (e.g., youth unemployment and poverty).

This article examines the substantive dimensions of the Eurozone crisis emphasising interconnections between inequality, exclusion and legitimacy. Section II briefly interrogates globalisation, the monetary union and austerity as central to current debates on the crisis. In Section III, the article seeks to develop a fresh critique of the crisis to argue that deep-seated institutional deficiencies and corruption are key drivers of rising inequality. Further, it proposes that the interaction of inequality and social exclusion is a critical element of the EU's legitimacy crisis. There are links between inequality, corruption and legitimacy. Finally, the article concludes with the assessment that austerity will fall short of the desired outcomes in the light of extreme divergence in economic conditions and governance practices.

\section{European Crisis: The Big Issues}

As key drivers of the legitimacy crisis, regional inequalities have been attributed to three major factors: accelerated globalisation; monetary union; and fiscal discipline.

\section{Globalisation and the loss of sovereignty}

The globalised economy of the 21 st century appears to have diminished the capacity of national authorities to exercise effective regulatory control over economic policy. The challenges posed by the Eurozone crisis have highlighted the need for well thought out policy responses that reach beyond the national sphere to correct institutional deficiencies and economic imbalances. Yet national responses still seem to be expounded as if the nation state were fully sovereign and dominant. Arguably, globalisation and Europeanisation have rendered moot the proposition that nation states are the masters of their destiny. A reluctance on the part of national elites to present the idea of 'more Europe' as a response to the economic rise of 'population behemoths like China and India' (Hill 2013) means that the starkness of the choice between 'banding together' or becoming 'less relevant and secure' is being obscured.

The process of European integration has lately coincided with the rise of China, India and Brazil as the expanded domains of global capitalism. Globalisation brings innovation, 'creative destruction' and inevitably winners and losers (Roubini 2012). The emerging economic powers have exerted much pressure on wages and the employment prospects of low-skilled and unskilled workers in the West (Roubini 2012). Europeanisation, exacerbated by the Global Financial Crisis (GFC) and the Eurozone crisis, has motivated many to resent free trade and the further surrender of national sovereignty to 'free' markets. Moreover, markets have recognised the flaw in the EU and Eurozone's architecture. Markets are spurred to action by decisions of credit agencies and institutional players in the global financial system, many of whom have to shoulder some responsibility for the GFC and its aftermath.

Yet, markets do not have long memories and the GFC testifies to the fact that they can fail to assess and even ignore valuable information to the detriment of taxpayers, jobs and the vulnerable (Taleb and Spitznagel 2012; Stiglitz 2012a). Former Italian Prime Minister Monti lamented, during a period of persistently high yields on Italian Government Bonds, the inability of financial markets to recognise the progress made by his government on fiscal and structural reforms (Wall 2012). Markets have longed for clear policy statements, backed up with unequivocal action that demonstrated beyond a doubt that the Eurozone and the ECB would provide protection for struggling states against insolvency, if only to ensure the integrity and continuing viability (and investor-friendly status) of the Eurozone. They were often left wondering. 
In theory, were they to be efficient, as economic theory suggests, the Euro markets ought to account for differences in productivity, risk, and frugality. The experience of the toxic lending in the USA and sovereign debt in Europe shows that, in reality, markets can fail to accurately assess risk (Weidmann 2012) and are prone to contagion (Stiglitz 2012b). Moreover, critical flaws in the financial architecture of EU have meant that stronger economies have little incentive to circulate surplus funds while weaker regions are exposed to panics and bank runs (Auerback 2012; Bibow 2012). Habermas notes that '[f]inancial markets have developed beyond the control of even the most powerful nation states' (Habermas 2012, 53). Only by acquiring greater 'political steering capabilities' and working towards 'a convergence of the member states' economic and social development' can the EU 'withstand the financial speculation' (Habermas 2012, 50). Market speculation has indeed prompted political elites to strengthen the executive capacity of the European Council to deal with the crisis, but the European Council's interventions have proved neither popular nor effective. Under German leadership it has pushed for tough austerity to balance national budgets and reforms to restore competitiveness.

There is a growing gap between the EU's supranational institutions and the European publics (Hill, 2013). Financial globalisation and the current finance-led model of growth have demanded the prioritisation of financial interests over all others. While banks have been bailed out by taxpayers, states are struggling to tame budgets to meet European and market demands - all at the cost of social cohesion. Not surprisingly, Europeans are judging this model negatively.

\section{The inadequacy of monetary union}

A key aspect of monetary union, as expressed in the Maastricht convergence criteria and the subsequent rules-based Stability and Growth Pact (SGP), was to target inflation expectations through monetary policy, restrict national budget deficits to less than 3\% of GDP and limit total national (sovereign) debt to $60 \%$ of GDP. The Maastricht criteria and SGP essentially featured a system of surveillance and coordination of fiscal policies among its member states. ${ }^{3}$ Despite the rules and the pro-SGP rhetoric, the failure of so-called 'core' governments to adhere to the limits has been striking. Germany departed from the Maastricht regime of $2 \%$ unit labour costs by wage deflation (Bibow 2012) and both France and Germany violated the 60\% debt rule (Feldstein 2011). This departure from the fiscal rules by the Eurozone's leaders was to have a detrimental effect when the GFC prompted stimulus spending in member states in a climate in which those states believed that the rules were meant to be violated.

The Fiscal Compact, a stricter version of the SGP, came into force on 1 January 2013 for ratifying states. The compact seeks to enforce budgetary discipline and, effectively, commits participating states to long-term austerity. It represents an intergovernmental response to a problem that demands an integrated political response. Hill (2013) has observed that ' $[\mathrm{t}] \mathrm{he}$ eurozone crisis has stretched EU governance to its limits because the EU's current political institutions are mostly adequate for a loose confederation of member states - but a loose confederation is inadequate for a monetary union.'

Indeed, as currently calibrated and constituted, monetary union is unable to deal with persistently divergent movements in prices and competitiveness across member states (De Grauwe 2012). It is worth noting that monetary union evolved at the heyday of deregulation and free-market ideology promising level-playing field, competition, market efficiency and welfare improvements. Also, the imperatives of financial deregulation and inflation targeting, as sufficient conditions for innovation and growth, reigned supreme.

However, it has now emerged that regulation and taxation can improve welfare (Stiglitz 2012b; Frank 2011) and a nation's capacity to adapt to economic change and convergence can be severely curtailed by extractive institutions (Acemoglu and Robinson 2012b). In addition, it is now apparent that pay does not always reflect productivity for all workers (Diamond and Saez 2012) and countries new to financial liberalisation are more vulnerable to debt crises than others (Reinhart and Rogoff 2011). 
Principal elements of the EU such as monetary union, free trade and capital movements, and fiscal discipline all rest on the contestable premises that (a) markets are always more efficient than government; that is, labour markets and prices adjust to reflect differences in productivity and social norms, and (b) adjustments are independent of institutional constraints, and income distribution. However, these assumptions are hard to reconcile with the Great Recession and even economic intuition (Stiglitz 2012b, Aghion and Cage 2012). The Great Recession has exposed the flaws of a monetary union as a mechanism of integration, in view of free capital movements, a restrained European Central Bank, and rigid fiscal rules. Moreover, this union seems incompatible with the ultimate goals of stability and prosperity for all the EU member states.

\section{Austerity and economic growth}

Sovereign debt crisis is often interpreted as a sign that a people live beyond their means and lack fiscal discipline. All too often the remedy proposed by the IMF in such cases has been austerity and the reduction of debt as a means to recovering business confidence and investment. Highly controversial claims of a direct link between public debt and stagnation (Herndon et al. 2013) have given impetus to the drive for austerity.

However, it has been argued that the focus on austerity when the servicing of the debt exceeds growth rates is a misdiagnosis of the problem. In fact, the right focus for Europe in that case should be on growth (Summers 2012). Although growth seems to be what Europe needs, the lack of fiscal discipline can be a risky strategy in the global world of banking and finance (Deen and Worrachate 2012). Austerity is thought essential to reduce debt and restore credit worthiness as well as market confidence in Europe, but the debt to GDP ratio will only increase in a recession which, in turn, perpetuates the austerity policy (Schulmeister 2012). The answer may be to strike a balance between growth and moderate inflation.

The debate on growth strategies so far has centered on structural reforms that foster competition and remove product and labour market rigidities. In theory, these reforms ought to enhance competitiveness, business confidence, and ultimately economic growth (ECB 2012). Although there is an increasing willingness to examine EU investments in education, innovation and growth-enhancing sectors such as energy (ECB 2012), there is still a pervasive emphasis on fiscal discipline and national stereotypes such as 'grasshoppers and ants' (Steffen 2012) or tax cheating (Elliot and Aitkenhead 2012).

Although these interpretations of sovereign debt allude to some core institutional failures, they fail to acknowledge that these failures associate with conflict of interest, uneven distribution of political power, and persistence of rent-seeking (Acemoglu et al. 2005, Bardhan 2005). Moreover, stark inequalities and social exclusion (e.g., youth unemployment) seem to perpetuate rent-seeking and severely impede institutional reform (Stiglitz 2012b; Alvaredo et al. 2013).

Furthermore, austerity, as a regressive policy, exacerbates inequality and undercuts a nation's capacity for reform and economic growth (UNDP 2011). A positive association between fiscal imbalances and corruption (Mungiu-Pipidi 2013) may give credence to the view that austerity may act as antidote to corruption. Yet again, causation may run in reverse - i.e., corruption and weak institutions in general lead to sovereign debt problems. If the latter holds true, austerity may reduce the resources available for corruption but it would not necessarily lead to better institutions.

With the swearing in of the new Juncker European Commission in November 2014, and the introduction of a Quantitative Easing (QE) program by the European Central Bank in January 2015 there is renewed hope that changed political circumstances will favour growth and investment over austerity. The full extent of the damage (material and symbolic) that austerity and inequality are inflicting on European societies has emerged. The IMF has questioned the effectiveness of its own bailout policies on Greece. ${ }^{4}$ Apart from burgeoning unemployment, social exclusion and poverty, there is a growing sense that the ideals of EI are vanishing. There is rising anger with political elites and 
general disenchantment with the EI project (ETUI 2013a). Moreover, the current EU failure to deliver adaptation and convergence to a European standard of living for all is raising questions of capacity, performance and legitimacy. The EP vote in May 2014 revealed the extent of disillusionment with the EU as Euroscepticism gained ground in core and peripheral member states alike. ${ }^{5}$ The outcome of the snap Greek election in January 2015 signalled the popular defeat of the bailout/austerity program in that country.

Political legitimacy and resilience in the era of globalisation also rest on the robustness of the European Union and the quality of institutions that have long-term impact on incentives and markets, and ultimately on growth and prosperity. The multi-dimensionality of legitimacy and its orientation to performance and social acceptability means that institutions that function optimally and deliver desired social and economic outcomes are more likely to be deemed legitimate. A more detailed discussion of legitimacy follows.

\section{Institutions, inequalities and democratic legitimacy}

Although globalisation, monetary union and fiscal austerity are important sources of discontent in the $\mathrm{EU}$, it is intuitive that inequality can be the product of social progress or policy errors. We maintain that these sources of inequality cannot rationally explain a sustained legitimacy crisis in the EU, for in the longer term, all other things being equal, creativity should dominate destruction and policy ought to be corrected.

Persistent popular challenges to the EU's legitimacy point to more fundamental causes of inequality that relate to social justice and fairness. Recent advances in economics advocate that institutional quality ${ }^{6}$ is a critical element of economic development (Acemoglu and Robinson 2012b). By its effect on transaction costs and incentives, institutional quality critically impacts on prices, innovation and economic growth. An important dimension of institutional quality is corruption in member states which can contribute to unsustainable deficits, market distortions, and extractive institutions. Corruption may be driven by either agency problems (Blackburn et al. 2010) - the principal (i.e., the public) delegates authority to an agent (i.e., executive government or public officials) who may use privileged information to their benefit and at the expense of the public - or 'collective action' problems (Persson et al. 2010) whereby lack of trust is so pervasive that the costs of containing corruption are much greater than the benefits for the perceived majority.

'Rent seeking' behaviors, such as corruption, monopoly power, and 'regulatory capture' exacerbate income inequalities (Stiglitz 2012b). Roubini $(2012,163)$ suggests that 'any economic model that doesn't properly address inequality by providing public goods and opportunity to all will eventually face a crisis of legitimacy.' Corruption and rent seeking undercut opportunities for the disadvantaged to upgrade their skills and to adapt to technological transformation. Consequently, rent seeking ultimately undermines macroeconomic stability, structural reform, and economic growth (Johnson et al. 2011; Stiglitz 2012b).

It has been argued that entrenched inequality associates with higher public debt, political instability (Roubini 2012; Kumhof and Ranciere 2010), extractive institutions (Krugman and Wells 2012; Acemoglu and Robinson 2012a) and the depletion of social capital (Wilkinson and Pickett 2009). The current focus on austerity and market reform does nothing to address the yawning inequalities afflicting many of the member states in crisis. In fact it makes it worse, as austerity tends to affect the disadvantaged most.

In economic theory, rising income inequality is justifiable when it reflects shifts to new technologies or new products (Acemoglu 2011; Yun 2006). However, increasing inequality can be unacceptable for several reasons: (a) it can be due to corruption, and 'cognitive capture' of public policy by interest groups and the rich (Johnson et al. 2011; Krugman and Wells 2012; Stiglitz 2012b); (b) it can add to economic crisis and public deficits; (c) it can lead to intergenerational exclusion and poverty 
(Alvaredo et al. 2013), and (d) it may lead to social unrest and political violence (Acemoglu et al. 2005; Bardhan 2005).

Social exclusion and unjustifiable inequality also impinges on economic growth. According to Aghion (2012), the success of EU reform hinges on the balance between fiscal discipline, growth, and social justice where the latter involves fairness and social inclusion. He argues that growth cannot be 'sustainable' when stark inequalities exclude many people from employment, dampen life aspirations and suppress work effort. Inclusive institutions are more conducive to skill development, innovation and growth (Acemoglu and Robinson 2012b). Commenting on the economic success of ancient Athens, Ober $(2008,266)$ also highlights the role of democratic institutions built on principles of accountability, transparency and legitimate dissent.

Until recently, the debate on institutional reform has been overly preoccupied with property rights (e.g., privatisation), labour market deregulation, and the inefficient state (Aghion and Cage 2012; Bardhan 2005). For example, corruption is almost exclusively discussed in terms of a rigid and selfserving public service (Mungiu-Pipidi 2013; Bardhan 2005). Yet, the role of rent-seeking and market power often goes unchallenged, although Boldrin and Levine (2013) and Stiglitz (2012b) are exceptions.

Income inequality due to institutional failure leads to resource misallocation and distorted incentives as it can strengthen the bargaining power of the rich to influence public policy (Stiglitz 2012b) and the wage structure (Alvaredo et al. 2013), both of which accentuate existing inequalities. In the absence of a 'level-playing field', policy capture by vested interests inevitably undermines public confidence in reforms, innovation, and investment in human capital.

The current debate on austerity is characterised by two polar views that both ignore the fundamental role of institutions. One view insists on fiscal re-distribution and an increasing role for state intervention while the other extreme pushes for austerity, piecemeal reforms and deregulation. However, both neglect that the 'level playing field' is work-in-progress, a common-interest state can be efficient, neither austerity nor its opposite abolishes extractive institutions, and 'market-supporting regulation' is critical for innovation and growth (Besley and Persson 2011).

\section{Legitimacy}

Democratic principles pertaining to representative and/or participatory democratic processes, now codified in the Treaty on European Union (TEU), ${ }^{7}$ are means by which civic participation in EU decisional processes can be stimulated. Articles 9-12 of the TEU are intended to encourage democratic participation. Important as these provisions may be in addressing the purported democratic deficit of EU decision-making, they are not intended to bring about a convergence within and between the member states themselves towards accepted standards of good governance. The EU member states are characterised by extreme divergence in the adherence to principles of democratic governance, which has been shown to distort markets and hamper EI. Within the Eurozone itself are states at virtually opposite ends of the spectrum of global rankings for corruption. ${ }^{8}$ As poor governance has similar deleterious, market-distorting consequences for EI as important constraints on economic development, there is a strong case for coordinated action at EU level to work towards correcting institutional and related deficiencies in the interests of integration.

For scholars, European integration has accentuated dilemmas of legitimacy. The role of undemocratic European institutions has received considerable attention since at least the 1990s (e.g. Banchoff and Smith 1999; Beetham and Lord 1998; Scharpf 1999; Schmidt 2013). For some time the draft Constitutional treaty was seen as a likely antidote to the legitimacy problem; a fresh opportunity to negotiate a compact between the EU and its citizens and thereby correct the deficiencies of an emerging political system. 
There are links between the failure of the Constitutional Treaty ${ }^{9}$ and the Eurozone crisis. Both may be attributed, at least in part, to a lack of certainty about the EU's direction. Whereas during the negotiation and ratification stages of the draft Constitutional Treaty, the single currency may have been seen as a stepping stone towards political union, the policy choices and loss of momentum associated with the eventual abandonment of the treaty meant that this perspective was lost (PisaniFerry and Sapir 2009, 69). The constitutional vision contemplated an acceleration of integration as a voluntary policy choice as citizens acknowledged the benefits of closer economic union and backed political union as a necessary corollary of economic and monetary union. Arguably the failure of the constitutional treaty stymied the push for greater political legitimacy and halted progress towards a form of political union that encompassed greater citizen participation in democratic processes and tighter fiscal integration. It is now evident that the imperfections of monetary union and the democratic deficit are both driven by a single cause: uncertainty about the aims of EI (The Economist 2012). Citizens are challenging the legitimacy of the EU's policies in the public space and in national constitutional courts. ${ }^{10}$

Legitimacy is often discussed in output-oriented and input-oriented terms (Scharpf 1999). Outputoriented legitimation is concerned with effectiveness and performance; effective results are for the benefit of the people. Instead, input-oriented legitimacy is about securing citizens' choices through participation by the people. Accordingly, political choices are legitimate if they are effective and reflect the 'will of the people'. To this analytical framework can be added so-called 'throughput' legitimacy' (Schmidt 2013). Having a focus on governance processes, throughput legitimacy is concerned with the efficacy, accountability and transparency of the EU's processes as well and their inclusiveness and openness to public consultation (Schmidt 2013, 2). While there are complementarities, interactions and tradeoffs between input and output legitimacy, it is thought that poor governance taints even effective and democratic outcomes:

[B]ad throughput - consisting of oppressive, incompetent, corrupt or biased governance practices - regularly undermines public perceptions of the legitimacy of EU governance, regardless of how extensive the input or effective the output (Schmidt 2013,3).

The EU's traditional concern in dealing with transnational problems has tended to focus attention on output-oriented legitimacy. However, the growth of EU competence in areas of high electoral salience, such as monetary and fiscal policy, has drawn attention to the need for greater democratic input in EU decision making. It is in this context that the blurring of legitimacy and democracy is most critical (Banchoff and Smith 1999). With its noticeable democratic deficits, EU governance is readily susceptible to the conclusion that it suffers from a legitimacy deficit as well. The motto 'Lavoro é Democrazia' (Work is Democracy) - catch-cry of uniform trade union protests in Rome on 22 June 2013 (Ronchini, 2013) - demonstrate the connections between employment, equality, social cohesion and democratic legitimacy. The connections are substantiated by the not so implicit threat that executive inattention to growing citizen demands for work will result in social discord and the demise of governments. Voters in Greece have ultimately made good on this threat. The UK referendum on EU membership further illustrates the potential for disenchanted voters to overturn unpopular executive bargains.

Although it is evident that nation states are no longer the repositories of undiluted national sovereignty and that membership of the EU and the Eurozone brings with it a surrender, or pooling, of national sovereignty in supranational institutions, the current concentration of legal powers in the Commission and the shifting of moral authority to the European Council (viz, Germany) to deal with the crisis have raised significant questions of legitimacy. These developments have effectively severed the longstanding binary between national and supranational institutions, introducing for the first time a direct and explicit relationship of dominance-submission among member states themselves. Stratham and Trenz $(2013,168)$ observe that public contestation about the winners and losers of integration is shattering the old universal premise that the EU is an equal partnership between countries and their citizens. 
The EU has taken a predominantly 'hands-off' approach on the question of correcting national maladministration. The Commission did not, until recently, have the power to bring national executives to account on issues of high political salience such as budgets. On the instigation of Germany and France in the mid-2000s the Commission's power to impose sanctions on member states in breach of the Stability and Growth Pact was deactivated. With Germany's insistence on fiscal consolidation and austerity during the debt crisis, divisions with other member states have surfaced. Moreover, by Germany assuming a leadership role in the crisis, the Commission has appeared, rightly or wrongly, as less of a policy innovator and more as an agent. This fundamental change raises new questions of legitimacy in terms of the authority of a powerful member state to impose unpopular solutions on the citizens of other member states.

The perennial question surrounding the absence of citizen approval of elite decisions on Europe has assumed new dimensions in the light of the current crisis: 'has anyone asked Europeans how much sovereignty they are ready to surrender to save the euro?' (The Economist 2012). If Europe chooses to continue to develop as an autonomous political system in order to make the euro work, it would ultimately need authority to do so. Conversely, the need to democratically legitimise EU would diminish if strategic institutional choices were exercised in favor of limited political integration.

Hix $(1999,364)$ suggested almost two decades ago that for integration to proceed much further the EU would need increased policy competence and greater democratic participation to legitimise outcomes. While increased policy competence has materialised in the monetary and fiscal spheres, this has not been accompanied by greater democratic participation. Habermas $(2012,50)$ opines that political legitimacy requires greater democratic influence by citizens over what their national governments may negotiate. Though irrefutable, these principles do not find firm expression in the EU's current institutional and governance arrangements.

Furthermore, it is becoming increasingly apparent that the legitimacy crisis afflicting EU institutions has also been driven by EU indifference or impotence to deal with bad governance and corruption at the national level (Mungiu-Pippidi 2013). This issue is closely connected with the EU's lack of leadership and problems of institutional design both at the EU and the member state level. Stark differences in equality within the EU, combined with persistent extractive institutions (Besley and Persson 2011) such as corruption, are inimical to the promise of shared prosperity and solidarity.

There is also growing fragmentation in the EU with the emergence of a multi-speed Europe (ETUI 2013a). With growing divergence there is social polarisation, increased risks of social exclusion and poverty (ETUI 2013b). If monetary union is not sustainable without social convergence, and monetary union is currently producing divergence, then it is clear that the EU is caught in a legitimacy trap that can only lead to Euroscepticism and populism. To gain greater acceptance Habermas (2012) suggests that the EU must demonstrate that it has the capacity to secure the EU's objectives in the interests of all of its member states and citizens. For this to come about the EU must acquire the capacity to confront institutional deficiencies in the member states, which impact on inequality and sustainable growth.

The need for effective institutions invites discussion of how the EU can promote convergence among its members around the principles of good governance. This imperative has been a point of discussion since at least the Commission's White Paper on Governance. ${ }^{11}$ The degree of divergence on this issue between and within member states suggests the need for concerted action on improving institutional frameworks and the targeting of specific problems in order to promote core principles of good governance, the absence of which has been shown to negatively impact on economic growth and development.

New initiatives and ideas by EU leaders have recently emerged that promise to revitalise the European vision for stability and shared prosperity. The Juncker Commission's focus on investment is an attempt to shift focus from austerity to growth. For some time the EU leadership has acknowledged the inadequacies of the existing system and has actively sought further integration with a more robust institutional structure of EU. Economic and political pressures in Italy, France, Spain and Greece 
motivated the former EU Commission president to call for a federation of states, ${ }^{12}$ and the ECB president for a 'banking union'. These announcements were designed to contain bank runs and relieve national governments from the responsibility to recapitalise banks, and for rising sovereign debt, and contagion. Institutional reform has been slow and piecemeal. The main focus of reform has been the strengthening of monitoring of national budgets by the Commission and greater coordination of fiscal objectives. Despite these changes, questions have persisted as to whose interests are being secured by EU policies and with what consequence. Doubts will remain until the citizens' interests in being represented by inclusive institutions that adhere to principles of good governance are prioritised over others. If this analysis is valid, it follows that the EU will fail to assert its legitimacy if it fails to achieve sustainable reductions in inequality and greater democratic participation.

\section{Conclusion}

The EU is confronted with division and extreme uncertainty regarding its future. The response to the fallout from the Great Recession has been piecemeal and inadequate. Seriously compromised now is the EU's core founding myth that integration leads to stability and growth for all its members; there are new power-holders, winners and losers of integration (Statham and Trenz, 2013, 164,168). The North, the rich, the banking sector may all be labeled winners at present, much to the dismay of ordinary workers and the newly unemployed in Southern Europe. Having played a leading role in causing the crisis, banks are dictating solutions despite evidence of 'regulatory capture' by ideology and vested interest (Stiglitz 2012b).

The sovereign debt crisis has revealed the inadequacy of the SGP and the absence of an effective crisis management system. Proposals for a banking union, eurobonds or other means of debt mutualisation have met resistance. Although the notion of collective responsibility - the defining element of solidarity - would provide a conceptual basis for burden sharing (Cook 2012, 508), it is not currently in evidence. Economic and social conditions in the member states differ widely.

There is general recognition among EU policy makers that the EU must act to achieve a degree of convergence in the fiscal and economic governance domain. Without some form of fiscal union, monetary union is incomplete. The latter requires a degree of homogeneity in regulations, public sector administration and governance rules. However, standards differ substantially amongst member states.

Moreover, the deficits are acquiring new dimensions. The performance or output-based legitimacy of EU decision-making, rarely seriously questioned in the past, has come into critical focus, with EU policymakers presenting austerity as the primary cure for the Eurozone's problems. EU policies that aim to avoid systemic risk in the Eurozone appear to be penalising debtor states and favouring others. Ultimately, austerity will not produce the desired effects against a background of extreme divergence in economic conditions, institutional quality and governance practices.

Equity considerations demand that the EU act to overcome the structural imbalances and deficiencies of monetary union and that it contribute to redressing national impediments to growth and development, whatever the source of such constraints may be, as such impediments distort the market. Just as the EU seeks to narrow development disparities among regions and member states through structural and cohesion funding, there is a need for the EU to act to equalise and optimise conditions for economic governance. Whether this can be achieved through monitoring and supervision or sanctions and incentives is a matter of debate. Lately, the European Commission has signaled its intention to adopt a stronger EU anti-corruption policy, although new EU legislation on corruption does not seem to be the favored approach at this stage. ${ }^{13}$ It appears the EU's commitment will not progress quickly beyond a reporting function in the absence of political will.

The abandonment of the Constitutional Treaty in 2005 set the scene for the erosion of EU centeredness over the last decade. The EU must tackle its legitimacy problem if it is to regain lost ground. 
Concerted EU action to achieve greater convergence towards good governance and growth can lay the foundations for a workable fiscal union, a reduction of inequality and, arguably, a more legitimate EU.

There is general recognition that the EU faces an unambiguous choice between the collapse of the European project or further integration towards a financial or fiscal union (Bibow, 2012). In response, and at the insistence of the Commission and Germany, debtor Southern states are making adjustments to align more closely to the Northern model of economic organisation. At the same time austerity, budgetary restraint and stronger fiscal coordination among Eurozone states with sanctions for noncompliance are being promoted as necessary safeguards against the collapse of the euro currency.

A lesson we are learning from the current crisis is that equity and social justice concerns must assume greater prominence in the hitherto arid discourse on the interventions necessary to stave off the collapse of the euro and economic decline. At stake is the legitimacy of EU action itself. The article has sought to demonstrate the link between poor institutions, persistent inequality, and the legitimacy deficit, assessed against output, input and throughput criteria. There is a need for further empirical research to establish the links between inequality, corruption and legitimacy and to complement the growing body of literature in this field. An examination of EU policy and scholarly literature invites the conclusion that the EU will continue to struggle to maintain its legitimacy unless it acts decisively to bring about a convergence of governance and sustainable growth to the benefit of all its citizens.

\section{References}

Acemoglu, D. (2011) On Inequality, The Browser, Interview. Online version accessed 14 December 2013, http://thebrowser.com/ interviews/daron-acemoglu-on-inequality.

Acemoglu, D. and Robinson J.A. (2012a) Against Political Capture: Occupiers, Muckrakers, Progressives. In J. Byrne (Ed) The Occupy Handbook, Back Bay Books, New York.

Acemoglu, D. and Robinson J.A. (2012b) Why Nations Fail: The Origins of Power, Prosperity, and Poverty, Crown Business, New York.

Acemoglu, D. et al (2005) Institutions as the Fundamental Cause of Long-Run Growth. In P. Aghion and S.N. Durlauf (Eds.) Handbook of Economic Growth, Vol. 1a, Elsevier, Amsterdam.

Aghion, P. (2012) Speech at the Brussels Economic Forum. Online version accessed 31 May 2012, http://ec.europa.eu/economy finance/bef2012/.

Aghion, P., and Cage, J. (2012) Rethinking Growth and the State. In O. Canuto and D.M. Leipziger (Eds.) Ascent After Decline: Regrowing Global Economies after the Great Recession, The World Bank, Washington DC.

Alvaredo, F., Atkinson, A.B., Piketty, T. and Saez, E. (2013) The top 1 percent in international and historical perspective. National Bureau of Economic Research (NBER), working paper 19075.

Auerback, M. (2012) Toward a workable solution for the Eurozone. Levy Economics Institute, Policy Note 2011/6.

Banchoff, T. and Smith, M.P. (1999) Legitimacy and the European Union: The contested polity, Routledge, London and New York.

Bardhan, P. (2005) Scarcity, conflicts and cooperation, MIT Press, Cambridge MA.

Beetham, D. and Lord, C. (1998) Legitimacy and the European Union, Longman, London and New York

Besley, T. and Persson, T. (2011) Pillars of Prosperity: The Political Economy of Development Clusters, Princeton University Press, Princeton, New Jersey.

Bibow, J. (2012) The Euro Debt Crisis and Germany's Euro Trilemma. Levy Economics Institute of Bard College, Working Paper 721, May.

Blackburn, K., Bose, N. and Haque, M.E. (2010) Endogenous Corruption in Economic Development. Journal of Economic Studies, 37 (1), pp. 4-28.

Boldrin, M. and Levine, D.K. (2013) The Case Against Patents'. Journal of Economic Perspectives, 27 (1), pp. 3-22.

Cook, K. (2012) Solidarity as a Basis for Human Rights Part One: Legal Principle or Mere Aspiration? European Human Rights Law Review, 5, pp. 504-515. 
Deen, M. and Worrachate, A. (2012) French Bond Yields Test Hollande's Economic Fealty, Bloomberg 24 April 2012. Online version accessed 12 August 2012 http://www.bloomberg.com/news/2012-04-24/french-bond-yields-test-hollande-s-economicfealty.html

De Grauwe, P. (2012) The Governance of a Fragile Eurozone, Centre for European Policy Studies, Working Paper No. 346.

Diamond, P. and Saez, E. (2012) Taxing High Earnings. In J. Byrne (Ed.) The Occupy Handbook, Back Bay Books, New York, pp. 317-329.

Dincer, O. and Gunalp, B. (2012) Corruption and Income Inequality in the United States, Contemporary Economic Policy, 30 (2), pp. 283-292.

Dixit, A.K. (2008) Economic governance. In S.N. Durlauf and L.E. Blume (Eds) The New Palgrave Dictionary of Economics, $2^{\text {nd }}$ edition, Palgrave Macmillan, London.

Elliot, L. and Aitkenhead, D. (2012) It is Payback: Don't Expect Sympathy. The Guardian, 25 May 2012.

European Central Bank (ECB) (2012) A Fiscal Compact for a Stronger Economic and Monetary Union, Monthly Bulletin, May, pp. 85-86.

European Trade Union Institute (ETUI) (2013a) Benchmarking Working Europe 2013. ETUI, Brussels.

European Trade Union Institute (ETUI) (2013b) IMF internal report on Greek bailout questions troika's austerity policy. Online version accessed 11 June 2013 http://www.etui.org/News/IMFinternal-report-on-Greek-bailout-questions-troika-s-austerity-policy.

Feldstein, M.S. (2011) The Euro and European economic conditions. NBER Working Paper 17617.

Frank, R. (2011) The Darwin Economy: Liberty, Competition, and the Common Good, Princeton University Press, Princeton, New Jersey.

Friedman, B. (2012) Round table discussion. Brussels Economic Forum webcast. Online version accessed 31 May 2012, http://webcast.ec.europa.eu/eutv/portal/archive.html.

Habermas, J. (2012) The Crisis of the European Union: A Response, Polity Press, Cambridge.

Herndon, T., Ash, M. and Pollin, R. (2013) Does High Public Debt Consistently Stifle Economic Growth? A Critique of Reinhart and Rogoff. Political Economy Research Institution, working paper 322, University of Massachusetdots Amherst.

Hill, S. (2013) Europe's Democracy Deficit: Putting Some Meat on the Bones of Habermas' Critique. Social Europe Journal. Online version accessed 3 June 2013 http://www.socialeurope.eu/2013/06/europes-democracy-deficit-putting-some-meat-on-the-bonesof-habermas-critique/

Hix, S. (1999) The Political System of the European Union, Macmillan Press, Houndmills.

Johnson, N.D., LaFountain, C.L. and Yamarik, S. (2011) Corruption is bad for growth (even in the United States). Public Choice, 147 (3-4), pp. 377-393.

Krugman, P. and Wells, R. (2012) The Widening Gyre: Inequality, Polarization, and the Crisis. In J. Byrne (Ed.) The Occupy Handbook, Back Bay Books, New York, pp. 7-17

Kumhof, M and Ranciere, R. (2010) Inequality, Leverage and Crises. IMF Working Paper, 10/268.

Longo, M. and Murray, P. (2011) No 'Ode to Joy': the European Union's Legitimacy Crisis. International Politics, 48, pp. 667-690.

Mungiu-Pippidi, A. (2013) The Good, the Bad and the Ugly: Controlling Corruption in the European Union. Hertie School of Governance, Policy Paper, March.

Ober, J. (2008) Democracy and Knowledge: Innovation and Learning in Classical Athens, Princeton University Press, Princeton, New Jersey.

Persson, A., Rothstein, B. and Toerell, J. (2010) The Failure of Anti-Corruption Policies: A Theoretical Mischaracterization of the Problem. The Quality of Government Institute, University of Gothenberg, Working Paper 2010: 19.

Pew Research Global Attitudes Project (2013), The New Sick Man of Europe: The European Union. Online version accessed 13 May $2013 \mathrm{http}: / /$ www.pewglobal.org/.

Pisani-Ferry, J. and Sapir, A. (2009) Euro Area: Ready for the Storm. In J. Pisani-Ferry and A.S. Posen (Eds) The Euro at Ten: The Next Global Currency? Peterson Institute for International Economics, Bruegel, Washington D.C. 
Ronchini, A. (2013) Unions Stage Protest in Rome, 22 June 2013. Online version accessed 10 July $2013 \mathrm{http}: / /$ www.demotix.com/ node/2181431

Reinhart, C.M. and Rogoff, K.S. (2011) This Time is Different: Eight Centuries of Financial Folly, Princeton University Press, Princeton, New Jersey.

Roubini, N. (2012) Economic Insecurity and Inequality Breed Political Instability. In J. Byrne (Ed.) The Occupy Handbook, Back Bay Books, New York, p. 157.

Scharpf, F. (1999) Governing in Europe, Oxford University Press, Oxford.

Schmidt, V. A. (2013) 'Democracy and Legitimacy in the European Union Revisited: Input, Output and Throughput'. Political Studies, 61(1), pp. 2-22.

Schulmeister, S. (2012) The economic consequences of the pact. Eurointelligence. Online version accessed 28 March 2012.

Statham, P. and Trenz, H-J. (2013) The Politicization of Europe: Contesting the Constitution in the mass media, Routledge, London and New York.

Steffen, T. (2012) Speech at the Brussels Economic Forum webcast. Online version accessed 31 May 2012, http://ec.europa.eu/economy finance/bef2012/.

Stiglitz, J. (2012a) Mitt Romney's Fair Share. Project Syndicate. Online version accessed 3 September 2012, http://www.project-syndicate.org/commentary/mitt-romney-s-fair-share-by-joseph-e--stiglitz.

Stiglitz, J. (2012b) The Price of Inequality, WW Norton \& Co., New York.

Summers, L. (2012) Austerity has brought Europe to the brink again. Online version accessed 30 April 2012 http://www.reuters.com/article/2012/04/30/column-summers-idUSL1E8FU2NX20120430.

Taleb, N. and Spitznagel, M. (2012) The Great Bank Robbery. Project Syndicate. Online version accessed 2 September 2012, http://www.project-syndicate.org/print/the-great-bank-robbery

The Economist (2012) The Commission Conundrum. Online version accessed 14 April 2012, http://www.economist.com/node/21552568? zid=307\&ah=5e80419d1bc9821ebe173f4f0f060a07.

United Nations Development Program (UNDP) (2011) Towards Human Resilience: Sustaining MDG Progress in an Age of Economic Uncertainty, UNDP, New York.

Wall, D. (2012) Italy's Monti warns of risks of European disintegration, The Wall Street Journal. Online version accessed 2 August 2012, www.wsj.com.

Weidmann, J. (2012) Global economic outlook - What is the best policy mix? Speech at the Economic Club of New York. Online version accessed 23 April 2012, http://bis.hasbeenforeclosed.com/review/r120425a.pdf.

Wilkinson, R. and Pickett, K. (2009) The Spirit Level: Why Greater Equality makes Societies Stronger, Bloomsbury Press, New York.

Yun, M. (2006) Earnings Inequality in USA, 1969-99: Comparing Inequality using Earnings Equations. Review of Income and Wealth, 52 (1), pp. 127-144.

\footnotetext{
Notes

'‘The New Sick Man of Europe: The European Union', Pew Research Global Attitudes Project, 13 May 2013 , $<$ http://www.pewglobal.org/>

${ }^{2}$ Institutions are humanly devised' rules and constraints that impact on economic behavior through incentives (Acemoglu et al. 2005).

${ }^{3}$ Council Regulation (EC) No.1466/97 of 7 July 1997 on the surveillance of and coordination of budgetary positions and economic policies OJ L209 02/08/1997, 1-5 as amended and Council Regulation (EC) No.1467/97 of 7 July 1997 on the implementation of the excessive deficit procedure OJ L209 02/08/1997 6-11 as amended. ${ }^{4}$ European Trade Union Institute, 'IMF internal report on Greek bailout questions troika's austerity policy' 11 June 2013. Online version accessed 5 July 2013 http://www .etui.org/News/IMF-internal-report-on-Greekbailout-questions-troika-s-austerity-policy.

${ }^{5}$ There was a particularly strong showing by populist anti-EU parties Front National in France and UKIP in the United Kingdom. See: European Parliament election: Eurosceptic parties claim victory in UK, France' $A B C$ News, 26 May 2014. Online version accessed 26 May 2014 http://www.abc.net.au/news/2014-05-26/europeanelection-ukip-national-front/5476776

${ }^{6}$ Key elements of institutional quality are voice and accountability, political stability, government effectiveness, regulatory burden, rule of law, and control of corruption (Dixit 2008),

$7^{1}$ Title II, OJ C 326, 26.10.2012.

${ }^{8}$ For instance, in the 2014 Corruption Perceptions Index, Denmark ranked first, while Italy, Greece, Bulgaria and Romania ranked equal $69^{\text {th }}$ out of 175 countries. Online version accessed 18 March 2015 http://www.transparency.org/cpi2014/infographic/global
} 
${ }^{9}$ The failure of this explicit constitutional process followed the rejection by French and Dutch voters of the draft Constitutional Treaty in 2005.

${ }^{10}$ For instance, the German Constitutional Court has made it clear that the transfer of sovereign powers to EU institutions in certain areas including finance is circumscribed. See, for example, the Maastricht Treaty Case (12 October 1993, BVerfGE 89, 155), and the recent judgment regarding the European Stability Mechanism (ESM), the EU's permanent bailout fund (12 September 2012, 2BvR 1390/12, 2BvR 1421/12, 2BvR 1438/12, 2BvR 1439/12, 2BvR 1440/12, 2BvE 6/12).

${ }^{11}$ White Paper on Governance, COM (2001) 428 final, 10. In its White Paper, the Commission identified the emerging norms of governance, derived from a liberal conception of democracy and democratic accountability openness, participation, accountability, effectiveness and coherence - as markers of legitimate action.

${ }^{12}$ Olli Rehn, opening address to Brussels Economic Forum, 31 May 2012; Barroso, Annual State of the Union address, Strasbourg, 12 September 2012.

${ }^{13}$ Cecilia Malmstrom, Fighting Corruption: From intentions to results', speech by the EU Commissioner for Home Affairs, 5 March 2013. 
